\title{
AMELIORATIVE ROLE OF ALPHA LIPOIC ACID ON PARACETAMOL INDUCED RENAL TOXICITY AND OXIDATIVE STRESS IN RATS
}

\author{
Maha A. Hilal ${ }^{1}$, Reda M. Elsayed ${ }^{1}$, Sheren F. Mahmoud. ${ }^{2}$, Amany A.Abdallah ${ }^{3}$, Sara E. \\ Kasem $^{1}$ \\ ${ }^{1}$ Forensic Medicine and Clinical Toxicology Department \\ ${ }^{2}$ Pathology Department \\ ${ }^{3}$ Clinical Pathology Department \\ Faculty of Medicine, Sohag University.Sohag, Egypt
}

Corresponding Author: Sara E. Kasem

E-mail:sara_alsayed86@yahoo.com

Postal address: Department of Forensic Medicine and Clinical Toxicology, Faculty of Medicine, Sohag University, Nasr city, Sohag, Egypt.

\section{ABSTRACT}

Background: Paracetamol, is the most widely used over-the-counter analgesic and antipyretic medication in the world, which has no adverse effect at therapeutic dosages. But in high doses causes renal failure. Objectives: The current study was designed to investigate paracetamol toxic effects upon the kidney and oxidative stress after repeated oral dose and evaluate possible protective effect of alpha lipoic acid when co-administered with and after paracetamol. Methods: forty eight white albino rats were divided equally into four groups. Each group was subdivided into two sub groups A \& B. Group I received gum acacia suspension. Group II received Alpha lipoic acid $(50 \mathrm{mg} / \mathrm{kg}$ ) orally. Group III received paracetamol (1 gm/ kg orally) for 4 weeks. Group IV received paracetamol and alpha lipoic acid at the same doses. Sub groups A were euthanized after 4 weeks, while sub groups B were euthanized after 8 weeks. Blood was collected for evaluation of kidney functions and oxidative stress markers. The kidneys were preserved for histopathological examinations. Results: The study proved that repeated administration of paracetamol induced disturbed kidney functions and oxidative stress. But this toxic effects decline markedly when alpha lipoic acid was co-administered with paracetamol. And more improvement occurs when ALA was administered for another 4 weeks after stoppage of paracetamol. Conclusions: The present study concluded that repeated paracetamol administration has nephrotoxic and oxidative stress effect and alpha lipoic acid has a protective effect against such harmful effects.

KEYWORDS: Paracetamol; renal toxicity, oxidative stress, Alpha lipoic acid.

\section{INTRODUCTION}

Paracetamol is one of the most commonly used antipyretic and analgesic drug in the world, which has no adverse effect when used at the therapeutic dose (Kanno et al., 2006).
It is available in more than 200 over the counter (OTC) and prescription medications, either singly or combined with other drugs (Patrick and Eugene, 2007).

Paracetamol is mainly metabolized via sulfation and 
glucuronidation pathways into nontoxic products (glucuronide and sulfate) that are excreted in the urine. Less than $5 \%$ of paracetamol is converted via the CYP (Cytochrome $\mathrm{P})$ pathway, in particular CYP2E1, into a highly toxic metabolite, $\mathrm{N}$ acetyl $p$ benzoquinone imine (NAPQI). NAPQI is rendered nontoxic by being conjugated to glutathione. With larger doses of paracetamol, the accumulation of high levels of NAPQI leads to depletion of glutathione (Ben-Shachar et al., 2012).

Paracetamol is the first step of the World Health Organisation (WHO) analgesic ladder for cure of cancer pain (Carlson, 2016). Also, it has been recommended as the first choice in long term treatment of mild to moderate pain in patients with chronic knee or hip osteoarthritis (Zhang et al., 2010).

Paracetamol toxicity may occur even at therapeutic dose in presence of risk factors as diabetes mellitus (Song et al., 1990), obesity (O'Shea et al., 1994) and chronic under-nutrition (Zhang et al., 1999).

Concomitant use of other medications, especially cytochrome $\mathrm{P} 450$-inducers, as isoniazid, rifampin, and phenytoin increases the risk of chronic paracetamol toxicity (Heard et al., 2012).

The kidney is the second target organ of paracetamol toxicity (Chen et al., 2015). Chronic use of paracetamol may lead to renal impairment which occurs in dose dependent manner (Perneger et al., 1994).

The paracetamol nephro-toxic effect occurs possibly due to local formation of NAPQI or other toxic metabolites from paracetamol by cytochrome $\mathrm{P} 450$ or COX enzymes (Bessems and Vermeulen, 2001).

Also, it is believed that lipid peroxidation and diminished antioxidant enzymes is a fundamental mechanism in paracetamol toxicity (Hinson et al., 2004).

Many researches have been peformed to discover and develop agents, which is protective against oxidative stress and have antioxidant effects (Knight et al., 2003).

Alpha-lipoic acid (ALA) is a wellknown natural antioxidant that is found in our diets, but appears to have more efficacy when given as a supplement (Wollin and Jones, 2003).

This metabolic antioxidant can scavenge a lot of of free radicals (Moini et al., 2002). In addition, ALA can regenerate endogenous antioxidants in the body as vitamin $\mathrm{C}$, vitamin $\mathrm{E}$ and intracellular reduced glutathione (GSH) (Wollin and Jones, 2003).

The present study aims to investigate paracetamol toxic effects on the kidney and its oxidative stress effect after repeated oral dose and evaluate the possible protective effect of alpha lipoic acid.

\section{MATERIALS \& METHODS} - Animals

48 albino rats were used. They were purchased from the animal house at Faculty of Medicine, Assiut University. They were kept in the animal house at Faculty of Medicine, Sohag University, in metal cages under ambient temperature, $21 \pm 3{ }^{\circ} \mathrm{C}$, and they were allowed to acclimatize to the condition of laboratory for 24 hours, then the 
treatment protocol was started. The ethics and husbandry conditions of animal research were considered and the study was approved by the Ethical Committee at Faculty of Medicine in Sohag University. Animals were fed with standard pellet feed and water.

\section{- Chemicals and Reagents}

- Kits of urea and creatinine were purchased from Beckman Coulter Inc. Company.

- Kits of superoxide dismutase and malondialdhyde were purchased from Bio diagnostic company.

- Paracetamol,

GlaxoSmithKline (abimol) from a commercial pharmacy.

- Alpha lipoic acid, Eva pharma (Thiotacid 300) from a commercial pharmacy.

- Gum acacia from a commercial market.

- Hematoxylin and eosin stains purchased from ALPHACHEMIKA

\section{- Instruments}

Apparatuses:

A- Beckman Coulter AU480 Clinical Chemistry System: Fully automated, Analytical Principles: Spectrophotometry and potentiometry. Present in Clinical Pathology Department - Sohag University Hospitals.

B- UV 2300 spectrophotometer (USA): It is a Split Beam Scanning UV-Vis Spectrophotometer which has a wave length range of 190-1100 nm and comes with a programmable 5turret sample compartment. Present in Faculty of Science, Sohag University.

C- Centrifuge, Hettich Zentifugen - model (EBA20) at
Clinical Toxicology laboratory, Sohag University

D- Micropipettes: HTL model: OP1000, OP100, serial micropipette.

E- Olympus CX 41 RF Light microscopy. At Pathology department at Faculty of Medicine, Sohag University.

\section{- Animals groups and methods}

48 male albino rats were used. The rats were divided randomly into 4 groups, 12 animals each; each group was subdivided into 2 sub-groups A, B.

Group I: Gum acacia was administered orally as $2 \mathrm{ml}$ of $2 \%$ suspension. Group IA was sacrificed after 4 weeks, while group IB was sacrificed after 8 weeks.

Group II: Alpha lipoic acid (ALA) was orally administered, dose $50 \mathrm{mg} / \mathrm{kg}$ /day (Pradhan et al., 2016) suspended in $2 \%$ gum acacia in dark bottle. Group IIA was sacrificed after 4 weeks, while group IIB was sacrificed after 8 weeks.

Group III: Paracetamol was orally administered, dose $1 \mathrm{~g} / \mathrm{kg}$ /day (Kiran et al., 2012 and Pachaiyappan et al., 2014) suspended in $2 \%$ gum acacia. Group IIIA was sacrificed after 4 weeks, while group IIIB was left without treatment for another 4 weeks then sacrificed.

Group IV: Group IVA was treated with paracetamol and ALA of the same previous doses for 4 weeks then sacrificed, while group IVB was treated with paracetamol and ALA for 4 weeks, then treated with ALA only for another 4 weeks then sacrificed.

\section{- Collection of samples}

Three ml of blood had been drawn from each rat from

Egypt J. Forensic Sci. Appli. Toxicol. 
cervical blood vessels during slaughtering into clean dry tubes. The serum was obtained immediately after sampling by centrifugation (4000 rpm for 5 minutes) for analysis of urea, creatinine and malondialdhyde.

- One ml blood was drawn in heparinized tube then centrifuged (4000 rpm for 10 minutes). Then aspirate off plasma. While RBCs was washed four times with $3 \mathrm{ml}$ of $0.9 \% \mathrm{NaCl}$ solution, centrifuging for $10 \mathrm{~min}$ at $4000 \mathrm{rpm}$ after each wash, then made up to $2 \mathrm{ml}$ with cold distilled water then stored at 70 c until analysis of superoxide dismutase.

- An autopsy was done for all animals where both kidneys were removed and preserved for histopathological examination.

\section{- Bio-chemical Tests:}

The serum biomarkers of renal function (urea and creatinine levels) were investigated.

Oxidative stress markers were investigated: super oxide dismutase and malondialdhyde, as well.

\section{- Histopathological Examination:}

The kidney was fixed in formalin $10 \%$ and paraffin embedding and cut at $5 \mu \mathrm{m}$ sections, hematoxylin and eosin (H\&E) stain was used. Sections were examined by light microscope then photographed.

\section{- Statistical Analysis:}

All statistical procedures were computed using the Statistical Program for Social Science (SPSS), version 16.0 computer software. SPSS Inc. Chicago, USA. All data were presented as mean \pm S.D and they were compared by Student's t-test and ANOVA. Significance was considered at p-value less than 0.05.

\section{RESULTS}

\section{Results of kidney functions tests:}

For urea, there was no significant statistical difference in mean values of serum urea between groups IA (50.33 $\mathrm{mg} / \mathrm{dl})$, IB (52.17 $\mathrm{mg} / \mathrm{dl})$, IIA (51.83 $\mathrm{mg} / \mathrm{dl})$ and IIB (52 mg/dl) where $\mathrm{P}$ value was 0.756 . As shown in table $\mathbf{1} \& \mathbf{3}$.

There was a significant statistical increase in mean value in group IIIA (70.83 $\mathrm{mg} / \mathrm{dl})$ as compared to group IA $(50.33 \mathrm{mg} / \mathrm{dl})$ and in group IVA (62.17 $\mathrm{mg} / \mathrm{dl})$ as compared to group IIA (51.83 $\mathrm{mg} / \mathrm{dl})$ where $\mathrm{p}$ values were $<0.001$, < 0.001 respectively. As shown in table $1 \& 3$.

Also, there was a significant statistical increase in mean values of serum urea in group IIIB $(58.17 \mathrm{mg} / \mathrm{dl})$ as compared to group IB $(52.17 \mathrm{mg} / \mathrm{dl})$ where $\mathrm{p}$ value was 0.006 , but there was no significant statistical difference in mean value of serum urea in group IVB $(50.83 \mathrm{mg} / \mathrm{dl})$ as compared to group IIB $(52 \mathrm{mg} / \mathrm{dl})$, where $\mathrm{p}$ value was 0.305 . As shown in table $1 \& 3$.

There was a significant statistical decrease in mean value of serum urea in group IIIB (58.17 $\mathrm{mg} / \mathrm{dl})$ as compared to group IIIA $(70.83 \mathrm{mg} / \mathrm{dl})$, where $\mathrm{p}$ value was 0.001 , and in group IVB $(50.83 \mathrm{mg}$ /dl) as compared to group IVA $(62.17 \mathrm{mg}$ /dl) where $\mathrm{p}$ value was $<0.001$. As shown in table $1 \& 3$.

There was a significant statistical decrease in mean value of serum urea in group IVA $(62.17 \mathrm{mg} / \mathrm{dl})$ as compared to group IIIA $(70.83 \mathrm{mg} / \mathrm{dl})$ where $\mathrm{p}$ value was 0.007 , and in group IVB $(50.83 \mathrm{mg}$ /dl) as compared to group IIIB $(58.17 \mathrm{mg}$ 
/dl) where $\mathrm{p}$ value was 0.004. As shown in table $1 \& 3$.

For creatinine, there was no significant statistical difference in mean values of serum creatinine between groups IA $(0.35 \mathrm{mg} / \mathrm{dl})$, IB $(0.34 \mathrm{mg} / \mathrm{dl})$, IIA $(0.35 \mathrm{mg} / \mathrm{dl})$ and IIB $(0.36 \mathrm{mg} / \mathrm{dl})$ where $\mathrm{P}$ value was 0.810 . As shown in table $\mathbf{2 \& 3}$.

There was a significant statistical increase in mean value in group IIIA (0.5 $\mathrm{mg} / \mathrm{dl})$ as compared to group IA $(0.35$ $\mathrm{mg} / \mathrm{dl}$ ) where $\mathrm{p}$ value was $<0.001$, but there was no significant statistical difference in group IVA $(0.36 \mathrm{mg} / \mathrm{dl})$ as compared to group IIA ( $\mathrm{p}$ value 0.935 ), as shown in table $\mathbf{2 \& 3}$.

Also, there was a significant statistical increase in mean value in group IIIB $(0.4$ $\mathrm{mg} / \mathrm{dl})$ as compared to group IB (0.34 $\mathrm{mg} / \mathrm{dl}$ ) where $\mathrm{p}$ value was 0.005 , but there was no significant statistical difference in mean value in group IVB $(0.34 \mathrm{mg} / \mathrm{dl})$ as compared to group IIB $(0.36 \mathrm{mg} / \mathrm{dl})$ where $\mathrm{p}$ value was 0.892 , As shown in table $2 \& 3$.

There was a significant statistical decrease in mean value of serum creatinine in group IIIB $(0.4 \mathrm{mg} / \mathrm{dl})$ as compared to group IIIA $(0.5 \mathrm{mg} / \mathrm{dl})$, where $\mathrm{p}$ value was 0.004 , and in group IVA $(0.36 \mathrm{mg} / \mathrm{dl})$ as compared to group IIIA $(0.5 \mathrm{mg} / \mathrm{dl})$ where $\mathrm{p}$ value was < 0.001 . As shown in table $\mathbf{2} \mathbf{\&} \mathbf{3}$

There was no significant statistical difference in mean value of serum creatinine in group IVB $(0.34 \mathrm{mg} / \mathrm{dl})$ as compared to group IVA $(0.36 \mathrm{mg} / \mathrm{dl})$, where $\mathrm{p}$ value was 0.846. As shown in table $2 \& 3$.

There was a significant statistical decrease in mean value of serum creatinine in group IVB $(0.34 \mathrm{mg} / \mathrm{dl})$ as compared to group IIIB $(0.40 \mathrm{mg} / \mathrm{dl})$ where $\mathrm{p}$ value was 0.034 . As shown in table $2 \& 3$.

Table (1): The mean values of serum urea in the different study groups.

\begin{tabular}{|c||c|}
\hline \multirow{2}{*}{ Groups } & Serum urea $(\mathrm{mg} / \mathbf{d l})$ \\
\cline { 2 - 3 } & Mean \pm SD \\
\hline \hline Group IA & $\mathbf{5 0 . 3 3} \pm \mathbf{3 . 6 1}$ \\
\hline \hline Group IB & $\mathbf{5 2 . 1 7} \pm \mathbf{1 . 4 7}$ \\
\hline Group IIA & $\mathbf{5 1 . 8 3} \pm \mathbf{4 . 0 2}$ \\
\hline Group IIB & $\mathbf{5 2 . 0 0} \pm \mathbf{3 . 4 1}$ \\
\hline Group IIIA & $\mathbf{7 0 . 8 3} \pm \mathbf{5 . 6 7}$ \\
\hline Group IIIB & $\mathbf{5 8 . 1 7} \pm \mathbf{4 . 0 2}$ \\
\hline Group IVA & $\mathbf{6 2 . 1 7} \pm \mathbf{2 . 6 4}$ \\
\hline Group IVB & $\mathbf{5 0 . 8 3} \pm 2.64$ \\
\hline
\end{tabular}

* SD: standard deviation 
Table (2): The mean values of serum creatinine in the different study groups.

\begin{tabular}{|c|c|}
\hline \multirow[b]{2}{*}{ Groups } & Serum creatinine (mg/dl) \\
\hline & Mean \pm SD $^{*}$ \\
\hline Group IA & $0.35 \pm 0.03$ \\
\hline Group IB & $0.34 \pm 0.03$ \\
\hline Group IIA & $0.35 \pm 0.05$ \\
\hline Group IIB & $0.36 \pm 0.04$ \\
\hline Group IIIA & $0.50 \pm 0.06$ \\
\hline Group IIIB & $0.40 \pm 0.03$ \\
\hline Group IVA & $\overline{0.36 \pm 0.03}$ \\
\hline Group IVB & $0.34 \pm 0.05$ \\
\hline
\end{tabular}

* SD: standard deviation

Table (3): Statistical comparison of serum urea and creatinine among different study groups

\begin{tabular}{||c|c|c||}
\hline \multicolumn{1}{|c|}{ Groups } & Serum urea & Serum creatinine \\
\cline { 2 - 3 } & P value by t- test & P value by t- test \\
\hline \hline IIIA versus IA & $<0.001$ & $<0.001$ \\
\hline IIIB versus IB & 0.006 & 0.005 \\
\hline \hline IVA versus IIA & $<0.001$ & 0.935 \\
\hline \hline IVB versus IIB & 0.305 & 0.892 \\
\hline \hline IIIA Versus IIIB & 0.001 & 0.004 \\
\hline IVA Versus IVB & $<0.001$ & 0.846 \\
\hline \hline IIIA Versus IVA & 0.007 & 0.001 \\
\hline \hline IIIB Versus IVB & 0.004 & 0.034 \\
\hline ** IA, IB, IIA and IIB & 0.756 & 0.81 \\
\hline \hline
\end{tabular}

* Significant difference at $\mathrm{p}$ value $<0.05$

** Analyzed by ANOVA test. 


\section{$\underline{\text { Results of oxidative stress markers }}$}

For MDA, there was no significant statistical difference in mean values of serum MDA between groups IA (5.65 $\mathrm{nmol} / \mathrm{ml})$, IB $(5.62 \mathrm{nmol} / \mathrm{ml})$, IIA (5.51 $\mathrm{nmol} / \mathrm{ml})$ and IIB $(5.50 \mathrm{nmol} / \mathrm{ml})$ where $\mathrm{P}$ value was 0.386. As shown in table 4 \& 6.

There was a significant statistical increase in mean values of MDA in group IIIA $(11.34 \mathrm{nmol} / \mathrm{ml})$ as compared to group IA $(5.65 \mathrm{nmol} / \mathrm{ml})$, and in group IVA $(8.10 \mathrm{nmol} / \mathrm{ml})$ as compared to group IIA $(5.51 \mathrm{nmol} / \mathrm{ml})$, where $\mathrm{p}$ values were $0.001,<0.001$ respectively, as shown in table $4 \& 6$.

There was a significant statistical increase in mean value in group IIIB (8.15 $\mathrm{nmol} / \mathrm{ml})$ as compared to group IB (5.62 $\mathrm{nmol} / \mathrm{ml}$ ) where $\mathrm{p}$ value was 0.001 , while there was no significant statistical difference in group IVB $(6.01 \mathrm{nmol} / \mathrm{ml})$ as compared to group IIB $(5.50 \mathrm{nmol} / \mathrm{ml})$ where $\mathrm{p}$ value was 0.128 . As shown in table $4 \& 6$.

There was non-significant statistical decrease in mean value in serum MDA in group IIIB $(8.15 \mathrm{nmol} / \mathrm{ml})$ as compared to group IIIA $(11.34 \mathrm{nmol} / \mathrm{ml})$ where $\mathrm{p}$ value was 0.063 . While, there was a highly significant statistical decrease in mean value in serum MDA in group IVB (6.01 $\mathrm{nmol} / \mathrm{ml})$ as compared to group IVA $(8.10$ $\mathrm{nmol} / \mathrm{ml}$ ) where $\mathrm{p}$ value was $<0.001$. As shown in table $4 \& 6$.

There was a significant statistical decrease in mean value in serum MDA in group IVA $(8.10 \mathrm{nmol} / \mathrm{ml})$ as compared to group IIIA $(11.34 \mathrm{nmol} / \mathrm{ml})$ where $\mathrm{p}$ value was 0.034 , and in group IVB (6.01 $\mathrm{nmol} / \mathrm{ml}$ ) as compared to group IIIB (8.15 $\mathrm{nmol} / \mathrm{ml}$ ) where $\mathrm{p}$ value was 0.003 . As shown in table $4 \& 6$.

For SOD, there was no significant statistical difference in mean values of serum SOD between groups IA (199.96 $\mathrm{u} / \mathrm{ml})$, IB $(200 \mathrm{u} / \mathrm{ml})$, IIA $(200.83 \mathrm{u} / \mathrm{ml})$ and IIB $(202.33 \mathrm{u} / \mathrm{ml})$ where $\mathrm{P}$ value was 0.876. As shown in table $5 \mathbf{\&} \mathbf{6}$.

There was a significant statistical decrease in mean values of SOD in group IIIA $(139.90 \mathrm{u} / \mathrm{ml})$ as compared to group IA $(199.96 \mathrm{u} / \mathrm{ml})$ and in group IVA $(169.93 \mathrm{u} / \mathrm{ml})$ as compared to group IIA $(200.83 \mathrm{u} / \mathrm{ml})$ where $\mathrm{p}$ values were < $0.001,<0.001$ respectively.

Also, there was a significant statistical decrease in mean values of SOD in group IIIB $(159.69 \mathrm{u} / \mathrm{ml})$ as compared to group IB $(200 . \mathrm{u} / \mathrm{ml})$ and in group IVB $(184.98 \mathrm{u} / \mathrm{ml})$ as compared to group IIB $(202.33 \mathrm{u} / \mathrm{ml})$ where $\mathrm{p}$ values were < $0.001,0.003$ respectively, as shown in table $5 \& 6$.

There was a significant statistical increase in mean value of serum SOD in group IIIB $(159.69 \mathrm{u} / \mathrm{ml})$ as compared to group IIIA $(139.90 \mathrm{u} / \mathrm{ml})$ where $\mathrm{p}$ value was 0.002, and in group IVB (184.98 $\mathrm{u} / \mathrm{ml}$ ) as compared to group IVA (169.93 $\mathrm{u} / \mathrm{ml}$ ) where $\mathrm{p}$ value was 0.002 as shown in table $5 \& 6$.

There was a significant statistical increase in mean value of serum SOD in group IVA $(169.93 \mathrm{u} / \mathrm{ml})$ as compared to group IIIA $(139.90 \mathrm{u} / \mathrm{ml})$ where $\mathrm{p}$ value was $<0.001$, and in group IVB $(184.98$ $\mathrm{u} / \mathrm{ml}$ ) as compared to group IIIB (159.69 $\mathrm{u} / \mathrm{ml}$ ) where $\mathrm{p}$ value was $<0.001$, as shown in table $5 \& 6$ 
Table (4): The mean values of MDA in the different study groups

\begin{tabular}{||c||c|}
\hline \multirow{2}{*}{ Groups } & MDA $(\mathrm{nmol} / \mathrm{ml})$ \\
& Mean \pm * SD \\
\hline \hline Group IA & $5.65 \pm \mathbf{0 . 2 5}$ \\
\hline \hline Group IB & $5.62 \pm \mathbf{0 . 3 0}$ \\
\hline \hline Group IIA & $5.51 \pm \mathbf{0 . 1 7}$ \\
\hline \hline Group IIB & $5.50 \pm \mathbf{0 . 2 7}$ \\
\hline \hline Group IIIA & $\mathbf{1 1 . 3 4 \pm 3 . 0 8}$ \\
\hline \hline Group IIIB & $\mathbf{8 . 1 5} \pm 1.2$ \\
\hline \hline Group IVA & $\mathbf{8 . 1 0 \pm 0 . 8 1}$ \\
\hline Group IVB & $\mathbf{6 . 0 1 \pm 0 . 4 8}$ \\
\hline \hline
\end{tabular}

* SD: standard deviation

Table (5): The mean values of SOD in the different study groups

\begin{tabular}{|c|c|}
\hline \multirow{2}{*}{ Groups } & $\overline{\mathrm{SOD}}(\mathrm{u} / \mathrm{ml})$ \\
\hline & 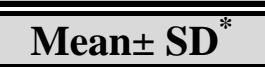 \\
\hline Group IA & $199.96 \pm 7.00$ \\
\hline Group IB & $200.00 \pm 7.87$ \\
\hline Group IIA & $200.83 \pm 12.42$ \\
\hline Group IIB & $202.33 \pm 15.25$ \\
\hline Group IIIA & $139.90 \pm 7.33$ \\
\hline Group IIIB & $159.69 \pm 8.78$ \\
\hline Group IVA & $169.93 \pm 7.07$ \\
\hline Group IVB & $184.98 \pm 5.17$ \\
\hline
\end{tabular}

* SD: standard deviation 
Table (6): The statistical difference of MDA and SOD in the different groups

\begin{tabular}{|c|c|c|}
\hline \multirow[t]{2}{*}{ Groups } & MDA & SOD \\
\hline & * P value by $\mathrm{t}$ - test & ${ }^{*}$ P value by $\mathrm{t}$ - test \\
\hline IIIA versus IA & 0.001 & $<0.001$ \\
\hline IIIB versus IB & 0.001 & $<0.001$ \\
\hline IVA versus IIA & $<0.001$ & $<0.001$ \\
\hline IVB versus IIB & 0.128 & 0.003 \\
\hline IIIA Versus IIIB & 0.063 & 0.002 \\
\hline IVA Versus IVB & $<0.001$ & 0.002 \\
\hline IIIA Versus IVA & 0.034 & $<0.001$ \\
\hline IIIB Versus IVB & 0.003 & $<0.001$ \\
\hline$* *$ IA, IB, IIA and IIB & 0.386 & 0.876 \\
\hline
\end{tabular}

* Significant difference at $p$ value $<0.05$

** Analyzed by ANOVA test.

\section{Histopathological results}

Group I: Haematoxylin and eosin (H\&E) examination of a kidney section of group I showed the normal histologic pattern of kidney parenchyma (fig 1).

Group II: H\&E stained slides of a kidney of group II exhibited the normal histologic pattern of kidney parenchyma, as well (fig 2).

Group IIIA: Stained slides of a section of kidney of group IIIA revealed marked hydropic degeneration of renal tubules in the form of swelling of the cells, small clear vacuoles in the cells cytoplasm and pale nucleus. There was widening of urinary space (figure 3).

Group IIIB: H\&E examination of group IIIB revealed moderate hydropic degeneration of renal tubules and moderate dilated congested blood vessels (figure 4).

Group IVA: Histo-pathological examination of group IVA revealed moderate hydropic degeneration of renal tubules (figure 5).

Group IVB: H\&E examination of group IVB revealed mild hydropic degeneration of renal tubules (figure 6). 


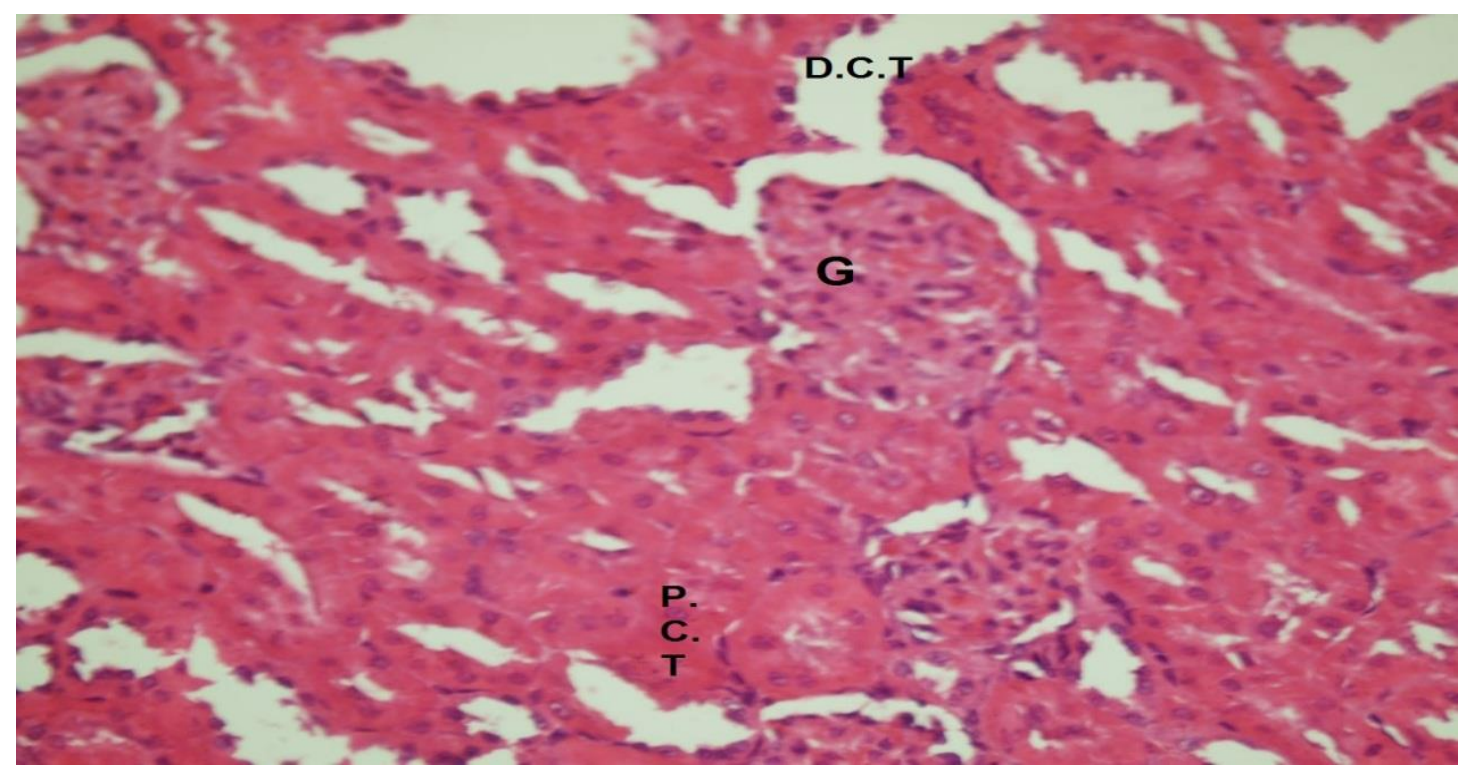

Figure (1): A photomicrograph of a section in the kidney of group I showing normal renal glomeruli (G), proximal convoluted tubules (P.C.T.) and distal convoluted tubules (D.C.T.) $\mathrm{H} \& \mathrm{E} \times 400$

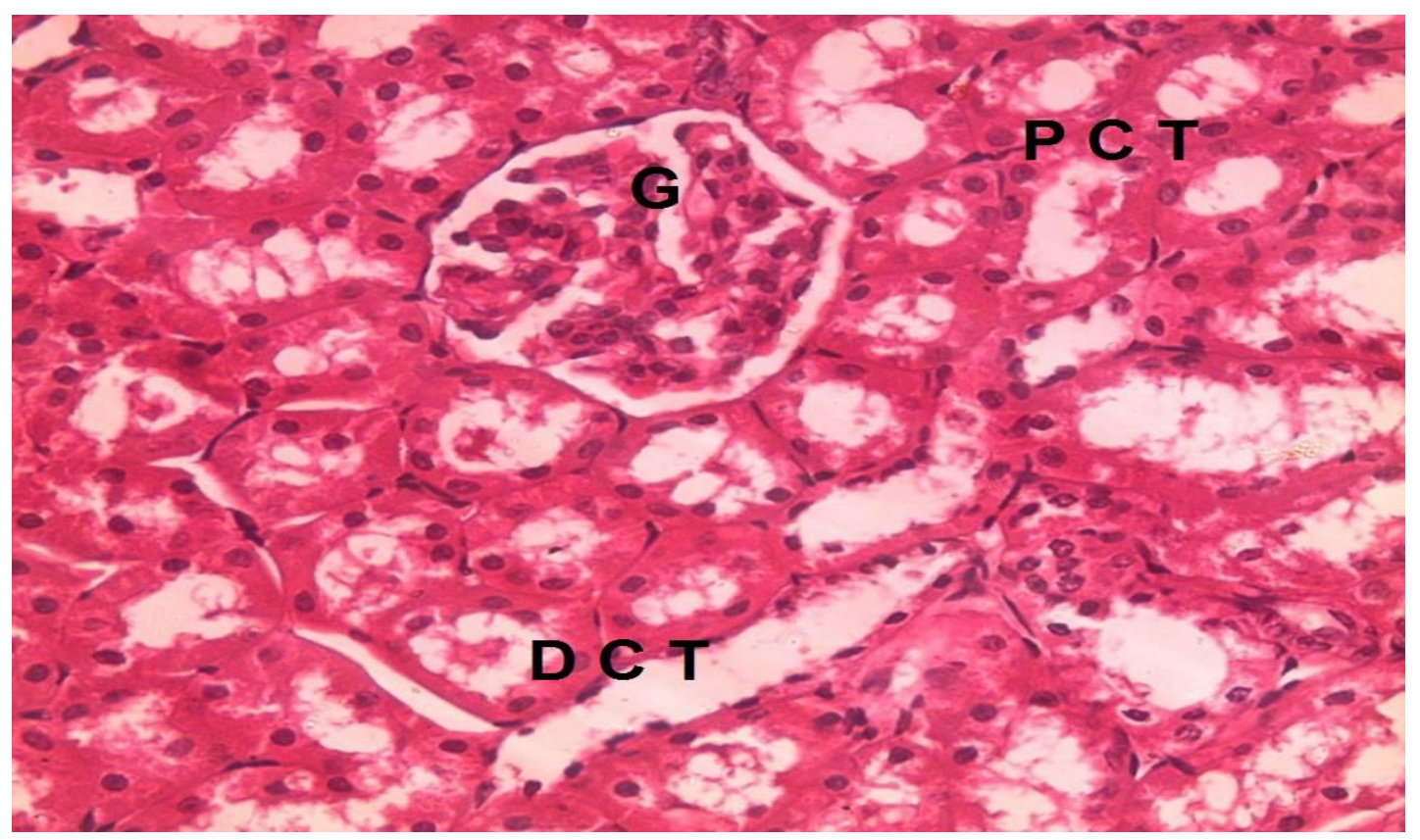

Figure (2): A photomicrograph of a section in the kidney of group II showing normal renal glomeruli (G), P.C.T. and D.C.T. H\&E x400. 


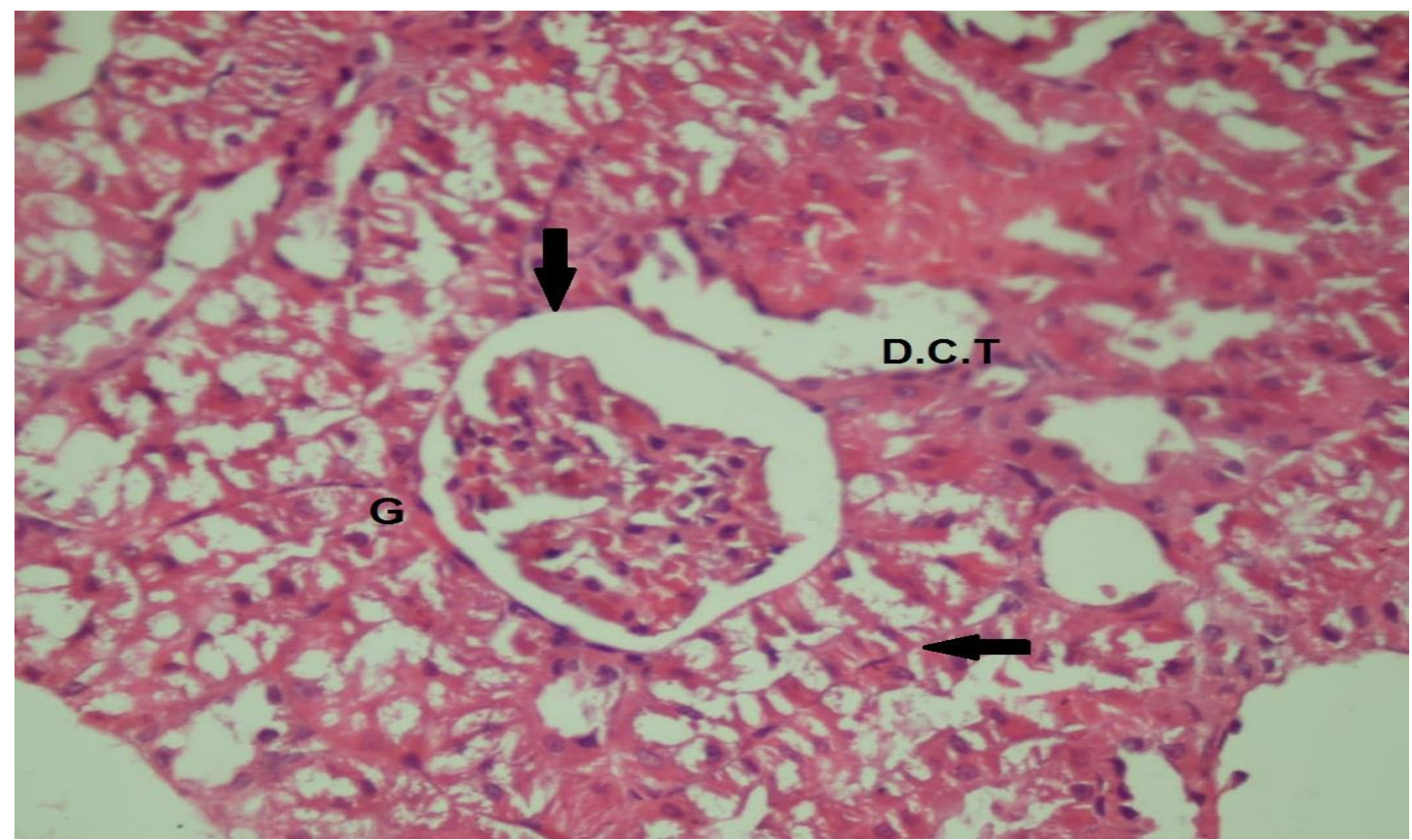

Figure (3): A photomicrograph of a section in the kidney of group IIIA showing widening of urinary space (vertical arrow) and marked vacuolar degeneration in D.C.T (horizontal arrow). $\mathrm{H} \& \mathrm{E} \times 400$.

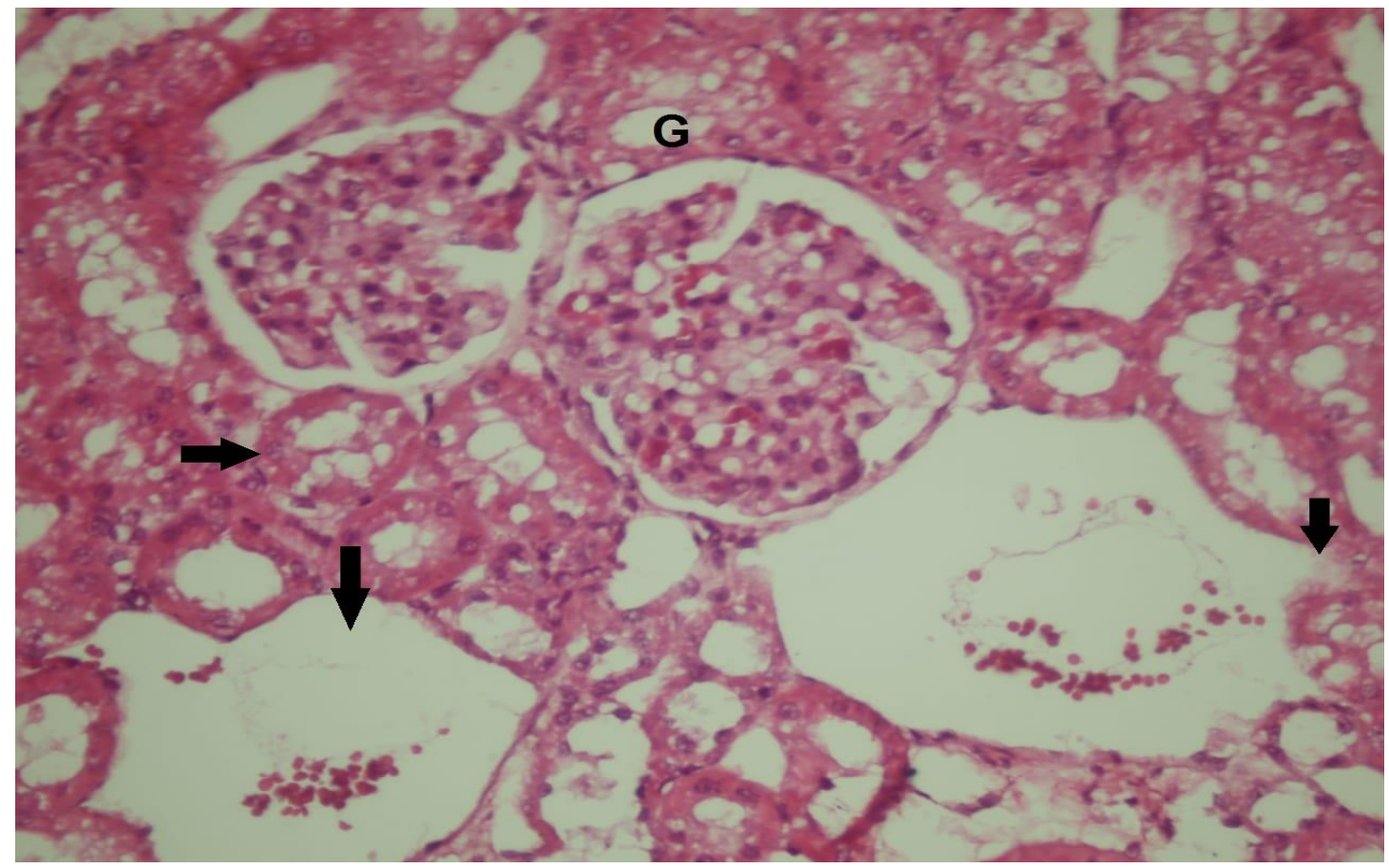

Figure (4): A photomicrograph of a section in the kidney of group IIIB showing moderate vacuolar degeneration in renal tubules (horizontal arrow) and moderate dilated and congested blood vessels (vertical arrows). H\&E x400. 


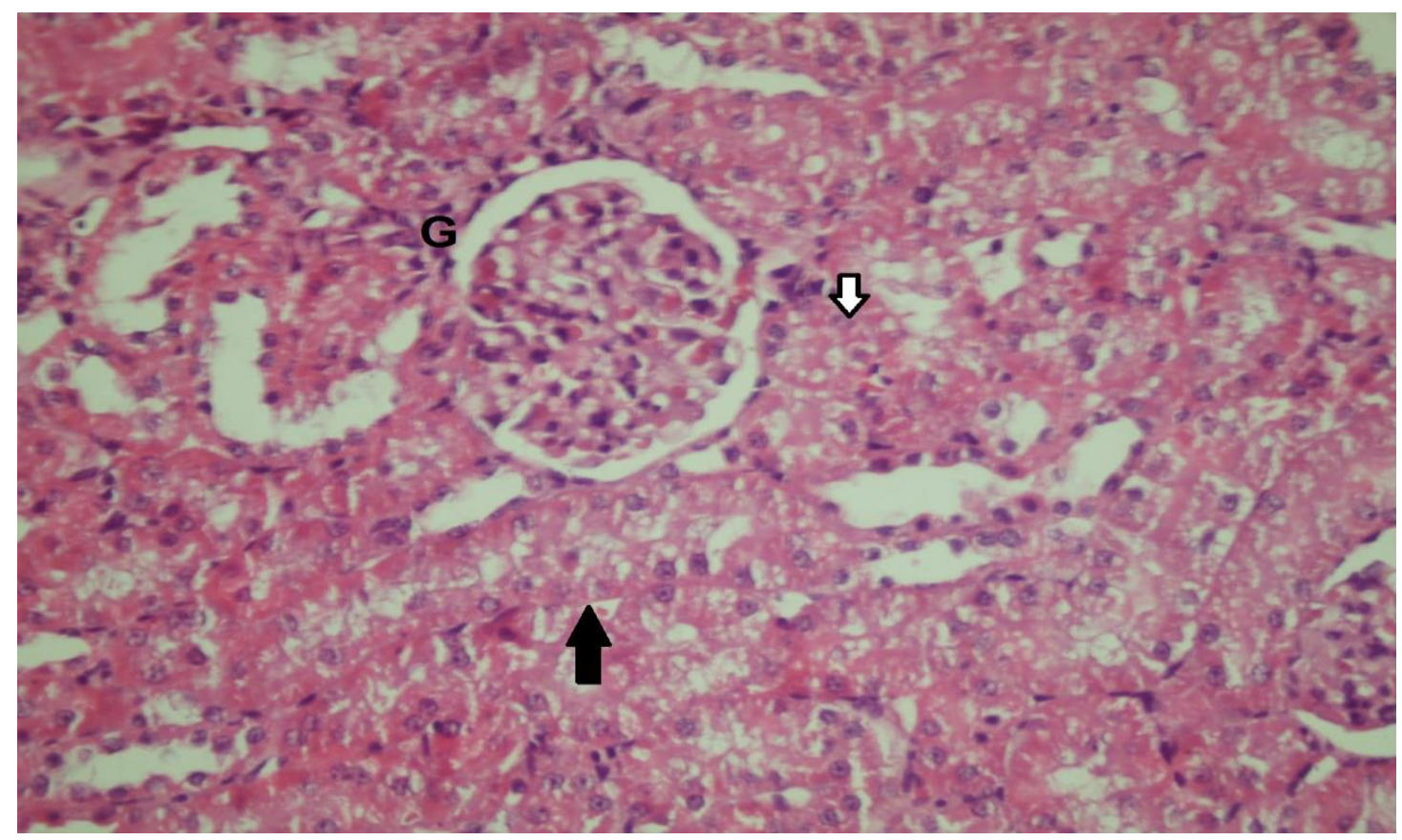

Figure (5): A photomicrograph of a section in the kidney of group IVA showing moderate vacuolar degeneration in P.C.T. (white arrow) and moderate vacuolar degeneration in D.C.T.(black arrow). $H \& E \times 400$.

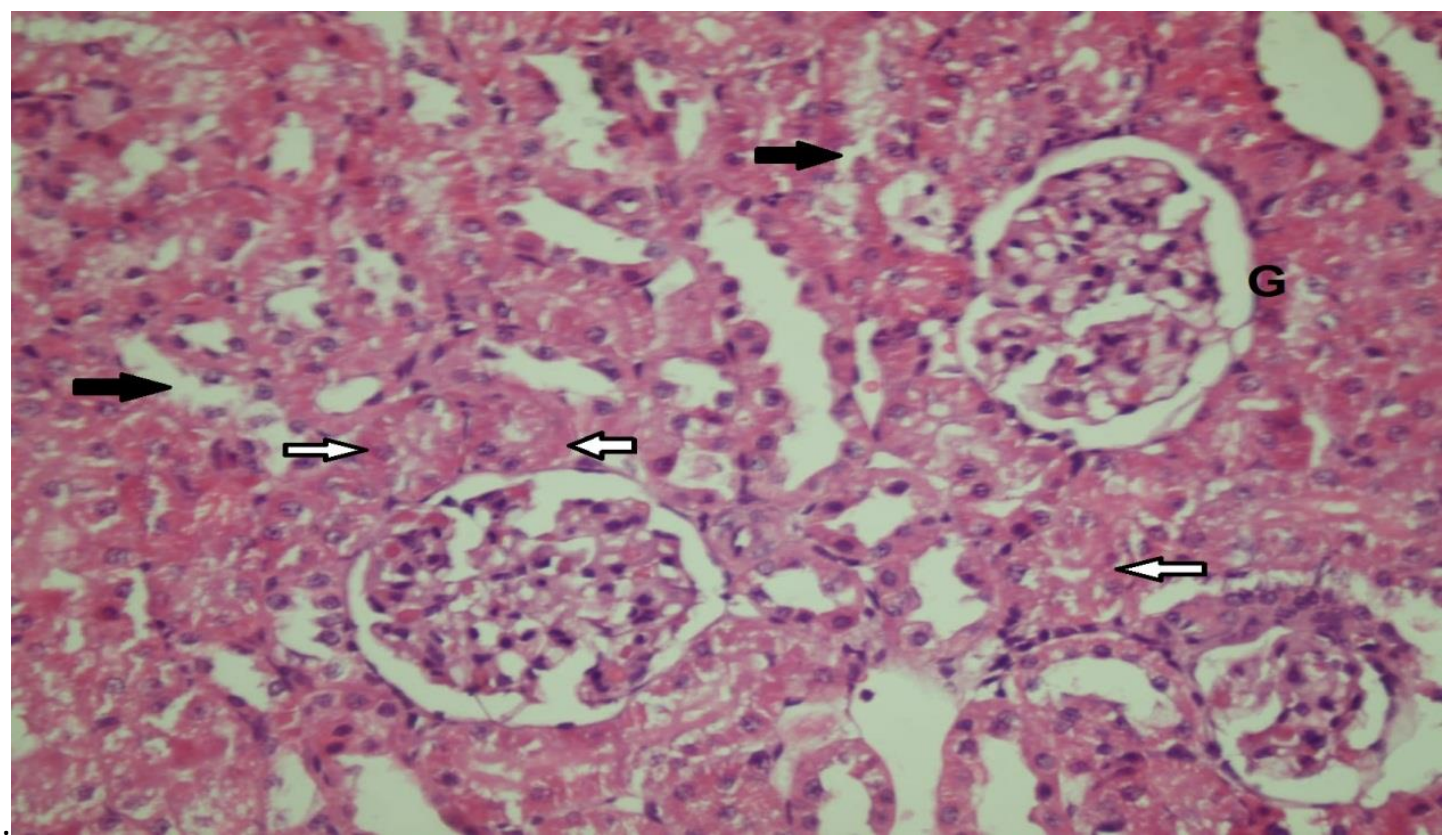

Figure (6): A photomicrograph of a section in the kidney of group IVB showing mild vacuolar degeneration in P.C.T (white arrow) and mild vacuolar degeneration in D.C.T (black arrow). $\mathrm{H} \& \mathrm{E}$ x 400. 


\section{DISCUSSION}

Paracetamol administration in high doses causes renal impairment in humans as well as animals (Pradhan et al., 2016). Toxicity of paracetamol is primarily due to its metabolism in the kidney and other tissues (Gu et al., 2005).

The present study was conducted in order to evaluate the nephro-toxic effects and oxidative stress of repeated oral administration of paracetamol to albino rats and study the effect of alpha lipoic acid on such toxicity.

In the current study, serum urea level showed a significant statistical increase with toxic dose of paracetamol and lesser increase when ALA was coadministered with paracetamol. Improvement of serum urea level occurred after period of recovery for 4 weeks. While, a better improvement followed a similar period of treatment with ALA.

There was a significant statistical increase in serum creatinine with the toxic dose of paracetamol, which did not occur when ALA was co-administered with paracetamol. Improvement occurred after recovery period following paracetamol administration but did not reach normal level as control.

Urea is a renal function biomarker as its rise means impairment of glomerular filtration which occurred with administration of paracetamol (Hamza and AL-Harbi, 2015). Creatinine is a more precise biomarker of renal function, it increases when glomerular filtration rate is reduced (Ismail et al., 2014).

In kidney diseases, urea level rises when its production exceeds its clearance rate, while the rise in the creatinine level occurs when nephrons are extensively damaged (Hamza and AL-Harbi, 2015).

Renal toxicity produced by paracetamol is due to its metabolism by oxidation to NAPQI, also its deacetylation to p-aminophenol which is further oxidized into amino-phenoxy radical as well as benzoquinone imine (Al-Harbi et al., 2015).

NAPQI is rendered non-toxic by being conjugated to reduced GSH unless amount of NAPQI formed exceed the cellular capacity for GSH conjugation. The extra NAPQI binds to cellular proteins and induce oxidative stress, leading to disturbance of cellular homeostasis and tubular damage (Covington and Schnellmann, 2008).

These results are in agreement with results accomplished by Yousef et al. (2010) who reported worsening of renal function in the form of a rise in the urea and creatinine levels when paracetamol was orally administered to rats at dose 650 $\mathrm{mg} / \mathrm{kg}$ for 15 days.

Also, Abdel-Zaher et al., (2008) reported that impairment of kidney function occurred when paracetamol was administered to rats at a dose of 750 $\mathrm{mg} / \mathrm{kg} /$ day for 7 days, which did not occur when ALA was co-administered orally at dose $25 \mathrm{mg} / \mathrm{kg} /$ day.

In addition, Saleh et al., (2018) reported that there was a significant rise in serum urea and creatinine when paracetamol was administered $(300$ $\mathrm{mg} / \mathrm{kg} /$ day for 30 days), which was lesser when moringa and marjoram were coadministered with paracetamol.

The present study show that administration of paracetamol resulted in a significant decrease in superoxide dismutase (SOD) and a significant increase in malondialdhyde (MDA) level 
as compared to control group. This was less evident when ALA was coadministered with toxic dose of paracetamol. Further improvement has occured when ALA was administered as a treatment for another 4 weeks after stoppage of paracetamol.

It has been reported that lipid peroxidation and diminished radicalscavenging enzymes is a fundamental in paracetamol-induced toxicity (Hinson et al., 2004).

It is believed that hydrogen peroxide $\left(\mathrm{H}_{2} \mathrm{O}_{2}\right)$ and superoxide anions are formed during the metabolism of paracetamol via $\mathrm{CYP}_{450}$ system and from mitochondria during paracetamol toxicity. It is also suggested that the production of reactive oxygen species (ROS) appears prior to intracellular glutathione (GSH) depletion and cell damage (Hamza and AL-Harbi, 2015).

The superoxide formation may stimulate peroxynitrite formation and nitration of proteins that may result in oxidative damage to proteins, DNA and lipids (Abdel-Zaher et al. 2008).

In addition, both paracetamol and NAPQI can interact with mitochondria, leading to reduction of mitochondrial glutathione content, decrease in ATP, and uncoupling of its respiratory chain associated with electron leakage (Donnelly et al. 1994)

Superoxide dismutase is declined by paracetamol toxic ingestion due to its consumption for detoxification of hydrogen peroxide released during metabolic activation of paracetamol (ElMegharbel et al., 2014). It is also known that antioxidant enzymes can be inactivated by lipid peroxides (AL-Harbi, 2015).

Lipid peroxidation, one of the oxidative stress effects, in which oxidative damage of lipids produce reactive oxygen species (ROS). Malondialdehyde (MDA) is a principal lipid peroxidation product that has an important value in the assessment of oxidative stress which is mediated by the production of NAPQI (S ener et al., 2005).

Alpha-lipoic acid is able to act as an antioxidant in both aqueous and lipid media of the cell (Moini et al., 2002).

The antioxidant properties of ALA and its reduced form are due to:

- Its ability to chelate transition metals thus inhibiting the formation of hydroxyl radical,

- Its capacity to scavenge reactive oxygen species and

- Its ability to regenerate endogenous antioxidants such as vitamin $\mathrm{C}$, vitamin $\mathrm{E}$ and GSH (Lu and Liu, 2002).

Our results agree with the results of Yousef et al. (2010) who reported that paracetamol administration, at dose 650 $\mathrm{mg} / \mathrm{kg}$ orally for 15 days, caused a significant inhibition in the antioxidant enzymes; Glutathione peroxidase (GPx), glutathione transferase (GST) and SOD in rat plasma and kidney.

Similar results were obtained by Abdel-Zaher et al., (2008). Their study revealed that ALA is able to defeat against paracetamol-induced nitrous oxide (NO) over-production, depletion of intracellular GSH and the increase of lipid peroxidation level.

The present results were in agreement with Pradhan et al. (2016) who stated that paracetamol overdose (500 mglkg ip for 10 days) resulted in a significant decrease in the SOD activities and significant increase in MDA level in plasma and kidney. When rats were coadministered with the ALA at two 
different doses (50-100 mglkg), the activity of SOD was increased and MDA was decreased significantly, and higher doses of ALA showed better response than lower dose.

Similar study was performed by Hamza and AL-Harbi (2015). The study discussed the protective effect of other antioxidants (silymarin and N. sativa extract) on paracetamol toxicity. It was proved that administration of paracetamol induced significant increase in the level of MDA and a significant decrease in the level of SOD, indicating an increase in the formation of free radicals, and there is an ameliorative role of both Nigella sativa extract and silymarin in improving the antioxidant capacities.

Saleh et al., (2018) studied the protecting effect of some Egyptian medicinal plants against paracetamol induced oxidative stress in rats, they concluded that the administration of Moringa or/and Marjoram are protective against oxidative damage of paracetamol as was confirmed by improvement of the measured parameters (MDA and GSH).

Opposite results were recorded by Lebda et al. (2013) where ginger was used as antioxidant instead of ALA, they reported that co-administration of ginger with paracetamol had a negative effects on hepatic antioxidant enzymes and reduced glutathione which may be due to the interaction between the herb and the drug.

In the present study, no abnormal finding was detected in the kidneys of control groups. While there was marked hydropic degeneration of renal tubules in the group received the toxic dose of paracetamol. Co-administration of ALA decreased the severity of damage to kidney tissue in the form of moderate hydropic degeneration of renal tubules.
Better improvement in the kidney histology occurred when ALA was administered for another 4 weeks after stoppage of paracetamol administration.

It is believed that proximal tubules are the part of the kidney which is more extensively affected by paracetamol toxicity due to their function in absorption and secretion (Seham and Awatef, 2008). Also, cytochrome p 450 is primarily localized in the proximal tubules which increase its susceptibility for toxicant injury by paracetamol (Covington and Schnellmann, 2008).

The un-injured tubular cells undergo a complex process of regenerating the destroyed renal parenchyma by restoring cellular function, de-differentiate, proliferate, migrate, and finally re-differentiate to restore morphologic and physiologic function to the damaged nephron (Covington and Schnellmann, 2008).

This is achieved by the presence of both endogenous renal stem cells and bone marrow stem cells which stimulate the gene upregulation and protein synthesis (Bussolati et al., 2005).

Better results were achieved by Abdel-Zaher et al., (2008), who observed moderate hydropic degeneration of proximal tubules and moderate congestion of distal tubules in paracetamol toxicity group received $750 \mathrm{mg} \mathrm{kg}$ for one week. This was not detected when ALA was used concurrently. The difference in the results may be attributed to the smaller dose of paracetamol and the shorter duration in comparison to the present study.

Saleh et al., (2018) reported that paracetamol (300 mg/kg/day for 30 days) induced congestion of the blood vessels in the renal cortex, focal inflammatory cells aggregation between the congested glomeruli and fibroblastic cells 
proliferation between the degenerated atrophied tubules. Adding of moringa or/and marjoram with paracetamol reduced the severity of these histopathological changes but some congestion in the cortical blood vessels with few inflammatory cells infiltration were still microscopically evidenced.

On the contrary, Yousef et al., (2010) reported that no histo-pathological affection of kidney occurred when paracetamol was administered to rats, at dose $650 \mathrm{mg} / \mathrm{kg}$ orally for 15 days. The difference in the result may be due to the smaller dose and the shorter duration of paracetamol administration.

Also, Ahmed et al., (2003) observed no histological changes in kidney tissue when paracetamol was administered (500 mg/kg /day) for 30 days, possibly due to the smaller dose.

\section{CONCLUSION}

It has been found that repeated oral administration of paracetamol affects the kidney both functionally and pathologically. Also, oxidative stress has occurred in the form of increase level of MDA and decrease level of SOD. Alpha lipoic acid is protective and even therapeutic against such harmful effect of paracetamol.

\section{RECOMMENDATIONS}

- It is advisable to restrict prolonged use of paracetamol to avoid its nephrotoxic and oxidative stress effect.

- $\quad$ Physicians should prescribe alpha lipoic acid when prolonged use of paracetamol is indicated as in cases of osteoarthritis or cancer pain.

- Clinical trials on the efficacy of ALA on sub-acute toxicity of paracetamol should be performed.
- Another experimental study on the efficacy of ALA in paracetamol toxicity with addition of negative control groups to confirm our results.

- Further studies should be performed on other antioxidants and evaluate its effect on paracetamol toxicity.

\section{REFERENCES}

Abdel-Zaher, A.O.; Abdel-Hady, R.H.; Mahmoud, M.M. and Farrag, M.Y (2008): The potential protective role of alpha-lipoic acid against acetaminophen-induced hepatic and renal damage. Toxicology, 243: 261-270.

Ahmed, M.H.; Balment, R.J. and Ashton, N. (2003): Renal action of acute chloroquine and paracetamol administration in the anesthetized, fluid-balanced rat. J. Pharm. Exp. Ther., 306(2): 478-483.

AL-Harbi M. S. (2015): Ameliorative effects of silymarin and Nigella sativa extract on paracetamol induced hyperlipidemia and oxidative stress in heart tissues in male mice. J. Chem. Pharm. Res., 7(3):925-933.

Al-Harbi, M.S.; Hamza, R.Z. and AlSofiani, T.A. (2015): Ameliorative roles of silymarin and Nigella sativa on hematological parameters and immunological capacities of male mice affected by paracetamol. Biosci. Biotechnol. Res. Asia, 12(1): 379-385.

Ben-Shachar, R.; Chen, Y.; Luo, S.; Hartman, C.; Reed, M. and Nijhout, H.F. (2012): The biochemistry of acetaminophen hepatotoxicity and rescue: a 
mathematical model. Theor.Biol.

Med. Model, 9:55-62.

Bessems, J.G. and Vermeulen, N.P. (2001): Paracetamol (acetaminophen)-induced toxicity: molecular and biochemical mechanisms, analogues and protective approaches. Crit. Rev. Toxicol., 31: 55-138.

Bussolati, B.; Bruno, S.; Grange, C.; Buttiglieri, S.and Deregibus, M.(2005): Isolation of renal progenitor cells from adult human kidney. The American Journal of Pathology, 166: 545-555.

Carlson, C. (2016): Effectiveness of the World Health Organization Cancer Pain Relief Guidelines: an integrative review. Journal of Pain Research, 9: 515-534.

Chen, Y.G.; Lin, C.L.; Dai, M.S.; Chang, P.Y.; Chen, J.H.; Huang, T.C.; Wu, Y.Y. and Kao, C.H. (2015): Risk of Acute Kidney Injury and Long-Term Outcome in Patients With Acetaminophen Intoxication: A Nationwide Population-Based Retrospective Cohort Study. Medicine (Baltimore), 94(46): 2040-2046.

Covington, M. D. and Schnellmann, R.G. (2008): Pharmacological aspects of nephrotoxicity .In: De Broe, M. E.; Porter, G.A.; Bennett, W.M. and Deray, G.(eds): Clinical Nephrotoxins Renal Injury from Drugs and Chemicals. 3 rd ed.chap.4.springer, Boston, MA: 7383.

Donnelly, P.J.; Walker, R.M. and Racz, W.J. (1994): Inhibition of mitochondrial respiration in vivo is an early event in acetaminopheninduced hepatotoxicity. Arch. Toxicol., 68:110-118.
El-Megharbel, S.M.; Hamza, R.Z. and Refat, M.S. (2014): Synthesis, spectroscopic and thermal studies of $\mathrm{Mg}$ (II), Ca (II), Sr (II) and Ba (II) diclofenac sodium complexes as anti-inflammatory drug and their protective effects on renal functions impairment and oxidative stress. Spectrochim Acta. A Mol. Biomol. Spectrosc., 135: 915-928.

Gu, J.; Cui, H.; Behr, M.; Zhang, L.; Zhang, Q.Y.; Yang, W. et al (2005): In vivo mechanisms of tissue selective drug toxicity: effects of liver-specific knockout of the NADPH-cytochrome P-450 reductase gene on acetaminophen toxicity in kidney, lung, and nasal mucosa. Mol. Pharmacol., 67: 623630.

Hamza, R.Z. and AL-Harbi, M.S. (2015): Silymarin and Nigella sativa extract ameliorate paracetamol induced oxidative stress and renal dysfunction in male mice. Asian Pac. J. Trop. Dis., 5(1): 169-174.

Heard, K.; Bui, A.; Mlynarchek, S.L.; Green, J.L.; Bond, G.R.; Clark, R.F. et al. (2012): Toxicity From Repeated Doses of Acetaminophen in Children: Assessment of Causality and Dose in Reported Cases. Am. J. Ther., 21(3):174-183.

Hinson, J.A.; Reid, A.B.; McCullough, S.S. and James, L.P. (2004): Acetaminophen-induced hepatotoxicity: role of metabolic activation, reactive oxygen/nitrogen species, and mitochondrial permeability transition. Drug Metab. Rev., 36(3-4): 805-822.

Ismail, H.A.; Hamza, R.Z. and ElShenawy, N.S. (2014): Potential 
protective effects of blackberry and quercetin on sodium fluoride-induced impaired hepato-renal biomarkers, sex hormones and hematotoxicity in male rats. J. Appl. Life Sci. Int., 1(1): 1-16.

Kanno, S.; Tomizawa, A.; Hiura, T.; Osanai Y., Kakuta M., Kitajima Y., et al (2006): Melatonin protects on toxicity by acetaminophen but not on pharmacological effects in mice. Biol. Pharm. Bull., 29: 472-476.

Kiran, P.M.; Raju, A.V. and Rao, B.G. (2012): Investigation of hepatoprotective activity of Cyathea gigantea (Wall. ex. Hook.) leaves against paracetamol-induced hepatotoxicity in rats. Asi. Pac. J. Trop. Biomed., 2(5): 352-356.

Knight, T.R.; Fariss, M.W.; Farhood, A. and Jaeschke, H. (2003). Role of lipid peroxidation as a mechanism of liver injury after acetaminophen overdose in mice. Toxicol. Sci., 76(1):229-236.

Lebda, M.A.; Nabil, M.T.; Mahdy, A.; Korshom, A.; Abd El-Wahab, A.M. and Raghda, I.G. (2013): Ginger (Zingiber officinale) potentiates paracetamol induced chronic hepatotoxicity in Rats. Journal of Medicinal Plants Research, 7(42): 3164-3170.

Lu, C. and Liu, Y. (2002): Interactions of lipoic acid radical cations with vitamins $\mathrm{C}$ and $\mathrm{E}$ analogue and hydroxycinnamic acid derivatives. Arch. Biochem. Biophys., 406:7884.

Moini, H.; Packer, L. and Saris, N.E. (2002): Antioxidant and prooxidant activities of -lipoic acid and dihydrolipoic acid. Toxicol. Appl. Pharmacol., 182: 84-90.
O'Shea, D.; Davis, S.N.; Kim, R.B.; Wilkinson, G.R. (1994): Effect of fasting and obesity in humans on the 6-hydroxylation of chlorzoxazone: a putative probe of CYP2E1 activity. Clin. Pharmacol. Ther., 56: 359-367.

Pachaiyappan, S.V.; Deecaraman, M.; Vijayalakshmi, M. and Sakthivelan, S.M.(2014):Subacute toxicity studies of acetaminophen in sprague dawley rats. Biological Pharmaceutical Bulletin, 37(7): 1184-1190.

Patrick, J. A. and Eugene, R. S. (2007): Acetaminophen safety and hepatotoxicity - where do we go from here. Expert Opinion on Drug Safety journal, 6: 341:355.

Perneger, T.V.; Whelton, P.K. and Klag, M.J. (1994): Risk of kidney failure associated with the use of acetaminophen, aspirin, and nonsteroidal antiinflammatory drugs. N. Engl. J. Med., 331: 1675-1679.

Pradhan S., Roy S., Mandal S., Samanta A., Patra, A., Das, K., Das S. and Nandi D.K. (2016): Protective effect of alpha-lipoic acid on hepato-renal toxicity, European J. Biomed. Pharmac. Sci., 3(5): 668674.

S sener, G.; Sehirli, O.; Cetinel, S.; Yeǧen, B.G.; Gedik, N. and Ayanog`lu-Du“lger, $\quad$ G.(2005): Protective effects of MESNA (2mercaptoethane sulphonate) against acetaminophen-induced hepatorenal oxidative damage in mice. J. Appl. Toxicol., 25: 20-29.

Saleh, N. S.; Allam, T.S.; El-Rabeaie, R.M. and El-Sabbagh, H.S. (2018): Protective effect of some Egyptian medicinal plants against oxidative stress in rats. Alexandria 
Journal of Veterinary Sciences, 58(1): 1-14.

Seham, H. R. and Awatef, A.M. (2008): Vitamin A against acetaminophen induced toxicity in the renal cortex in the renal cortex of albino rats. Egypt.J.Histol., 31: 321-331.

Song, B.J.; Veech, R.L. and Saenger, P. (1990): Cytochrome P450IIE1 is elevated in lymphocytes from poorly controlled insulin-dependent diabetics. J.Clin. Endocrinol. Metab., 71: 1036-1040.

Wollin, S. D. and Jones, P. J. H. (2003): $\quad \alpha$-Lipoic Acid and Cardiovascular Disease. J. Nutr., 133(11): 3327-3330.

Yousef, M.I.; Omar, S.A.; El-Guendi, M.I. and Abdelmegid, L.A. (2010):

Potential protective effects of quercetin and curcumin on paracetamol-induced histological changes, oxidative stress, impaired liver and kidney functions and haematotoxicity in rat. Food Chem.Toxicol., 48: 3246-3261. Zhang, W.; Nuki, G.; Moskowitz, R. W.; Abramson, S.; Altman, R. D.; Arden, N. K. and Tugwell, P. (2010): OARSI recommendations for the management of hip and knee osteoarthritis. Osteoarthritis and Cartilage, 18(4): 476-499.

Zhang, W.; Parentau, H.; Greenly, R.L.; Metz, C.A.; Aggarwal, S.; Wainer, I.W. and Tracy, T.S. (1999): Effect of protein-calorie malnutrition on cytochromes P450 and glutathione S-transferase. Eur. J. Drug Metab. Pharmacokinet., 24: 141-147. 


\section{الملخص العربي}

الدور الوقائي لحمض الالفا ليبويك في حاله التسمم الكلوي والاجهاد التأكسدي من عقار الباراسيتامول في

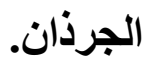

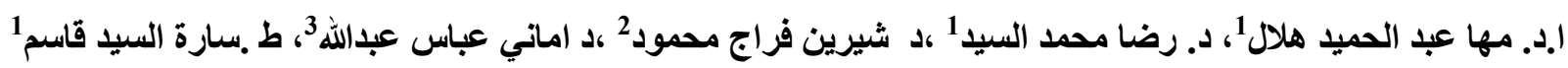

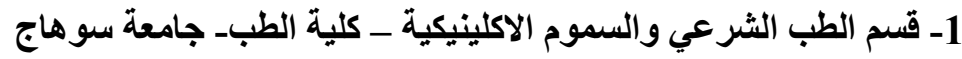

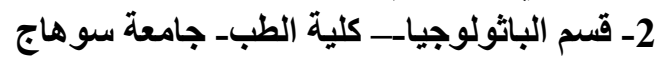

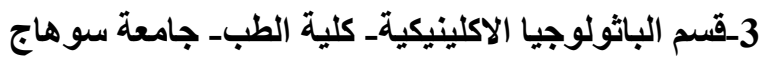

المقدمة: يعد البار اسيتامول من أكثر الأدوية المسكنة و الخافضة للحرارة و التي تستخدام دون وصفة طبية ـ ويمتاز بأنه لا يتسبب

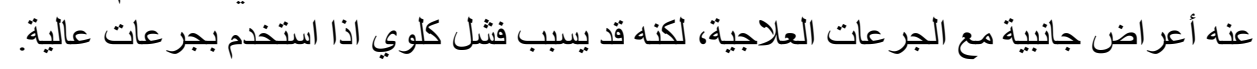

الهذف من الدراسة: تهدف هذه الدراسة الي دراسه سميه عقار البار اسيتامول علي الكلي والاجهاد التاكسدي الذي يحدث من

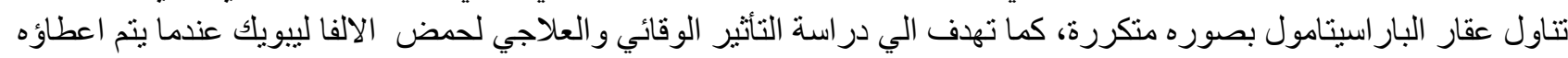

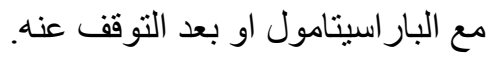

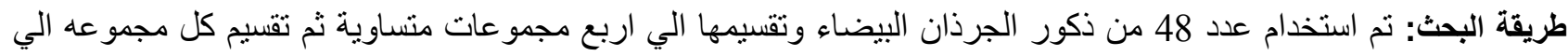

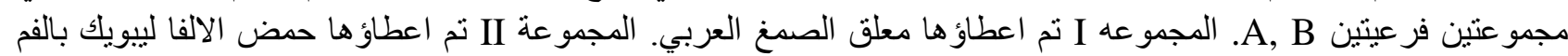

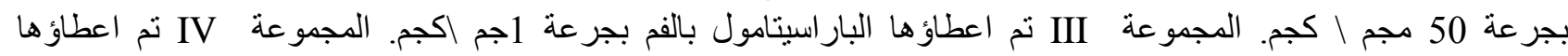

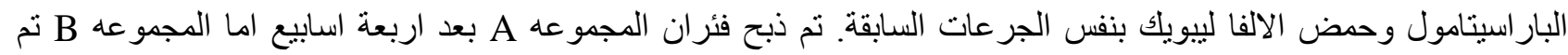

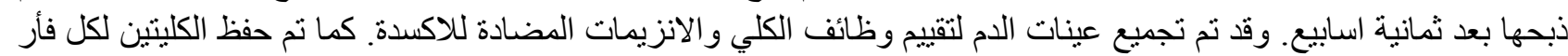
لار اسة التغير ات الباتولوجية للكلي.

النتائج: أنتبت النتائج ان تناول البار اسيتامول بجرعات زائدة متكررة يؤدي الي اضطر اب وظائف الكلي وانخفاض ف الانزيم

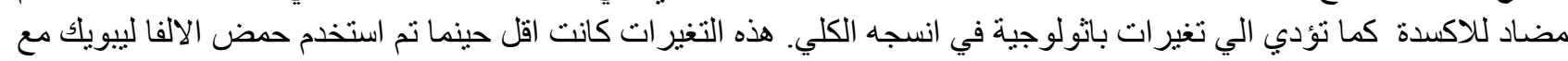

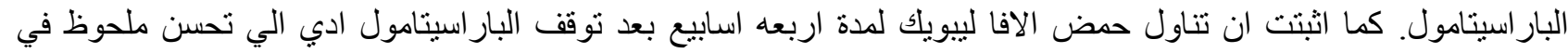

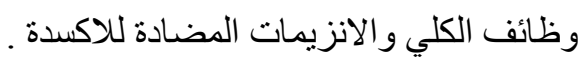

الاستتتاج: خلصت الدراسة الي ان تناول البار اسيتامول بجر عات عاليه يؤدي الي خلل في وظائف الكلي واجهاد تاكسدي. كما

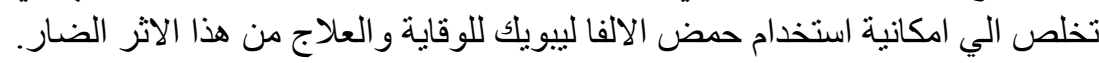

